\title{
Long PCR Product Sequencing (LoPPS): a shotgun-based approach to sequence long PCR products
}

\author{
Sébastien F Emonet, Gilda Grard, Nadège M Brisbarre, Grégory N Moureau, Sarah Temmam, Rémi N Charrel \& \\ Xavier de Lamballerie \\ Unité des Virus Emergents (EA3292, IFR48, IRD UR034), Faculté de Médecine, 27 boulevard Jean Moulin, 13005 Marseille, France. Correspondence should be addressed \\ to X.d.L. (xavier.de-lamballerie@medecine.univ-mrs.fr).
}

Published online 1 March 2007; doi:10.1038/nprot.2006.453

\begin{abstract}
Here we describe a practical procedure for sequencing long PCR products. The method relies on ultrasonic shearing of PCR products, resulting in fragments $700-1,000$ nt long. Termini are subsequently repaired to obtain blunt ends and 3' A-overhangs are added before TA cloning. A predetermined number of clones are sequenced using an insert-independent primer to obtain an overlapping contig covering the full length of the PCR product. This method is cost effective and enables the complete sequencing of any large PCR product in a high-throughput format. Processing of amplified DNA requires $3 \mathrm{~h}$ handling time prior to the ligation step, and the clone library is available $2 \mathrm{~d}$ later. The complete sequence information is obtained approximately $5 \mathrm{~d}$ after the PCR step, depending on the sequencing procedure adopted.
\end{abstract}

\section{INTRODUCTION}

Overview of high-throughput sequencing strategies

The shotgun-based strategy-the technique of preference for sequencing large DNA genomes-has been used for the complete genome characterization of a range of eukaryotes and prokaryotes ${ }^{1-6}$. Genomic DNA is sheared into $2-50 \mathrm{kbp}$ fragments ${ }^{2}, 3^{\prime}$ and $5^{\prime}$ ends are repaired and cloned into a bacterial vector to produce a library. The $700 \mathrm{bp}$ terminal regions of these clones are sequenced with insert-independent vector primers ${ }^{7}$, and the complete sequence is reconstructed from overlapping fragments. Large-scale sequencing projects have spurred on recent technical improvements to reduce the cost and time required to obtain single-sequence resolution. These advances consist mainly of alternatives to creating bacterial libraries and to Sanger sequencing biochemistry ${ }^{8}$. Hence, integrated sequencing procedures that include library production, DNA amplification, sequencing and contig assembly have recently been developed ${ }^{9,10}$. These technologies still rely on random DNA shearing but enable the separation of individual template molecules on beads and their independent amplification in a cell-free system by emulsion $\mathrm{PCR}^{11}$. Sequencing is subsequently performed on each bead, using pyrosequencing ${ }^{12}$ or sequencing by ligation ${ }^{10}$ rather than the traditional Sanger method.

However, the use of such integrated sequencing pipelines seems inappropriate when applied to RNA virus genomics. First, viruses are small, intracellular parasites for which large amounts of the targeted genetic material must be separated from the host nucleic acids to construct the library. This requires preliminary steps of tissue culture and ultracentrifugation before shearing and cloning ${ }^{13}$. In addition, the required yields of nucleic acids are difficult to obtain when working on RNA viruses and/or low-replicating viruses. Such a strategy is time consuming, difficult in the case of clinical samples and hazardous with human pathogens. Second, viral RNA genomes are usually small and/or segmented (1-10 kbp molecules). Third, RNA virus genomes frequently consist of short conserved motifs interspersed with long regions displaying high levels of genetic heterogeneity. Therefore, a common sequencing strategy consists

of amplifying and sequencing long PCR products obtained using primers targeting the most conserved regions. For these reasons, standard viral RNA genomics has relied on 1-5 kbp RT-PCR amplifications followed by primer-walking, which involves de novo synthesis of specific primers to extend sequencing to undetermined regions. Characterization of a $4 \mathrm{kbp}$ sequence by this method requires at least six rounds of sequencing. Design and synthesis of new primers make this strategy expensive and time consuming.

Alternative procedures can be divided into three groups. The first consists of replacing Sanger sequencing biochemistry with cheaper and faster technologies, such as pyrosequencing or sequencing by ligation-hybridization. However, their short read length, limited to $100 \mathrm{bp}$, is poorly adapted to high-throughput sequencing of short genomes. The second alternative avoids de novo primer synthesis by making use of a premade oligonucleotide library. Primers may be: (i) 5-10mer oligonucleotides randomly synthesized that are used either alone $e^{14-16}$ or in a modular combination ${ }^{17-22}$ or (ii) oligonucleotides resulting from high-throughput synthesis ${ }^{23,24}$. To date, the size of the required oligonucleotide libraries limits the use of these methods. The indexer walking ${ }^{25}$ method has recently been proposed: DNA is submitted to cycles of digestions followed by terminal ligation of oligonucleotide adaptors ('index'). One end of the cloned DNA is sequenced with M13 universal primer, and this first sequence is analyzed to find specific endonuclease restriction sites close to its $3^{\prime}$ end. DNA is digested with the selected enzyme before ligation of a specific double-stranded indexer, amplified by PCR and submitted to Sanger sequencing primed with the indexer. These steps are repeated and allow unidirectional progress into the unknown sequence. As the indexer library is considerably smaller than those previously proposed, indexer walking might be a costattractive method as it avoids systematic primer synthesis. However, the procedure remains time consuming for the following reasons: (i) the choice of the indexer is a function of the nucleotide sequence determined in the previous cycle and (ii) experimental 
handling for a single cycle of digestionligation involves DNA amplification and DNA purification by gel purification, ethanol precipitation and streptavidin-coated beads.

\section{Overview of the LoPPS technique}

The third alternative uses the shotgun strategy to create, from a PCR product, a DNA library of fragments short enough to allow one-step complete sequencing. One major advantage of the shotgun strategy is the potential for automation of the entire process. Automation of bacterial growth, plasmid DNA purification and sequencing enables rapid sequencing of numerous large DNA genomes to high-quality standards with attractive cost profiles. We have developed the long PCR product sequencing (LoPPS) procedure (see Fig. 1) on the basis of this shotgun strategy. Three to five kilobasepair PCR products, generated by any standard PCR or RT-PCR method, are randomly sheared by ultrasound into $\sim 700$ bp DNA fragments. The protruding termini are repaired to create blunt ends and $3^{\prime}$ A-overhangs added to allow TA cloning and to avoid fragment concatenation. The number of clones required for contig reconstruction is predicted from the length of the initial PCR product (see Table 1 and ref. 36). Clones are randomly selected and sequenced with the T7 PROM vector primer. Finally, the target sequence is reconstructed from overlapping fragments.

\section{Applications of the LoPPS technique}

Although this strategy was originally developed for application to RNA virus genomics, it can be applied to any PCR product regardless of its origin. Long PCR amplification protocols were first developed by Barnes ${ }^{26}$ and Cheng ${ }^{27}$ to study large human and bacteriophage genes. Long PCR amplifications are now involved in numerous biological molecular studies: constructions of viral infectious clones ${ }^{28-30}$; cloning and expression of large-protein

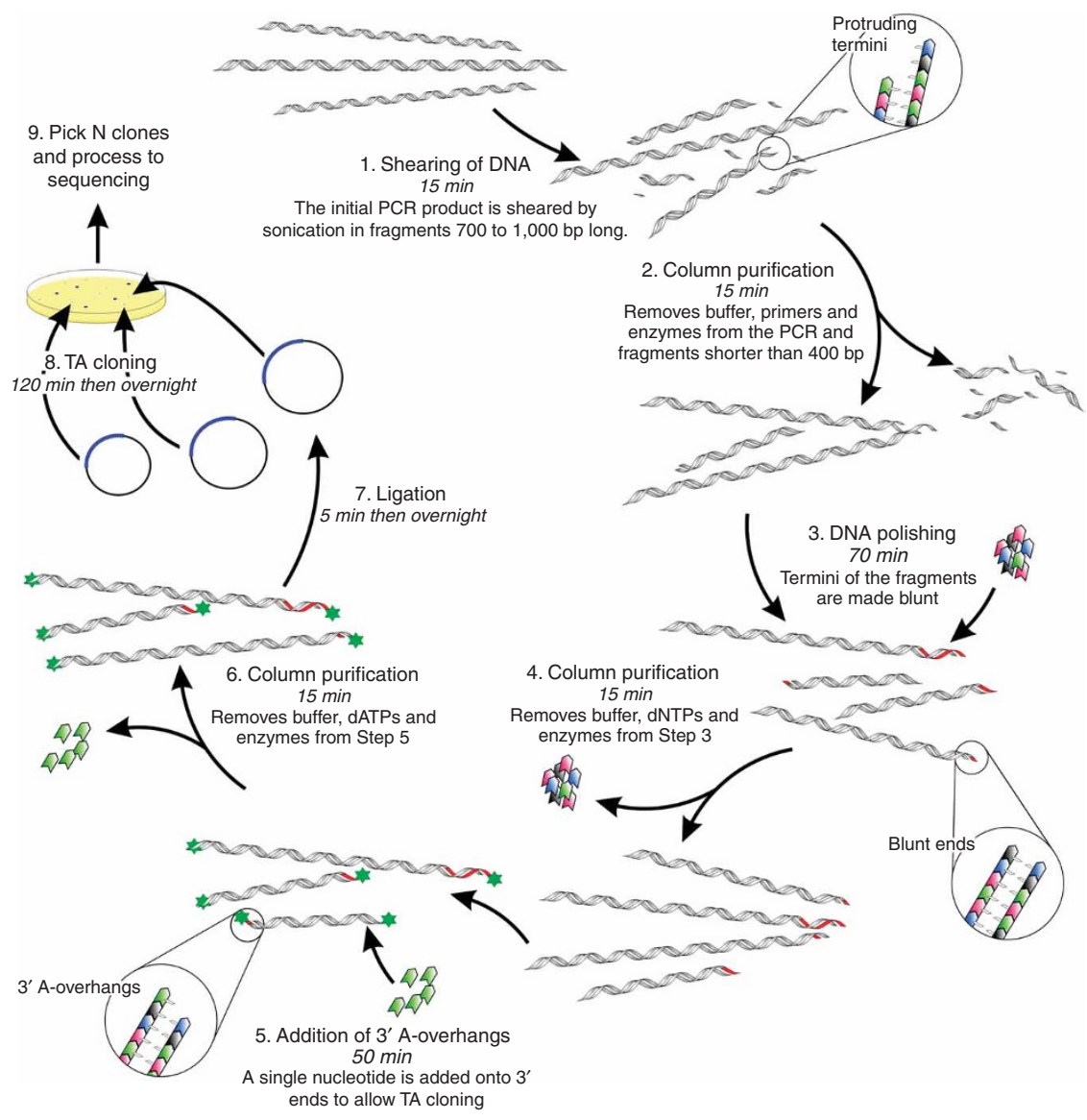

Figure 1 | Schematic diagram of the LoPPS procedure.

genes $^{31}$ for structural or functional studies; replacement of the standard subcloning strategy ${ }^{32}$; and site-directed mutagenesis ${ }^{33,34}$. Sequence determination of the cloned DNA is crucial to such applications for which LoPPS may be a convenient tool.

\section{Advantages of the LoPPS technique}

This procedure requires amounts of amplified DNA as low as 100-200 ng, a result that cannot be achieved with the primer-walking method. Such amounts are also consistent with the yields of long RT-PCR for which high DNA concentrations may be difficult to achieve. In addition, the method gives access to an evaluation of the

TABLE 1 | Number of clones to be sequenced.

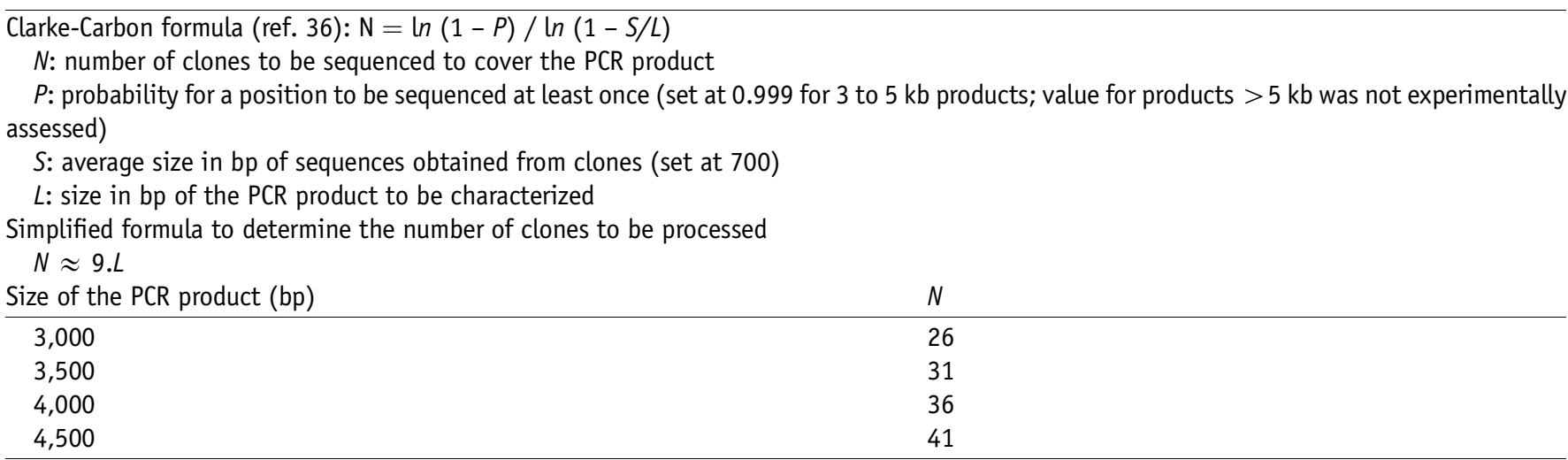


genetic variability as each nucleotide position is read several times (four times on average following the proposed protocol). A single operator can process up to six PCR products at the same time in $3 \mathrm{~h}^{30}$ until the ligation step, and preliminary gel purification is not necessary unless nonspecific amplifications are observed. LoPPS does not require sophisticated laboratory equipment and is based on a combination of simple molecular biology manipulation protocols. Taking advantage of the use of automated high-throughput sequencing platforms, the current price of LoPPS is roughly one-third of that of primer-walking per nucleotide position. We have used the LoPPS technique successfully to characterize a large number of PCR products ranging from $\sim 2.5$ to $5 \mathrm{kbp}$. Although not verified in our laboratory, the protocol published here should allow the characterization of larger products simply by determining the number of clones to sequence using the provided formula.
MATERIALS

\section{REAGENTS}

- Nanosep 100K columns purification (VWR, cat. no. 516-8520) A CRITICAL Columns commonly used for standard PCR products purification did not enable a satisfactory removal of small fragments resulting from DNA shearing by sonication

- DNA Terminator End Repair Kit (Lucigen, cat. no. 40035-2)

- Taq DNA polymerase, $10 \times$ PCR buffer, $50 \mathrm{mM} \mathrm{MgCl}_{2}$ (Invitrogen, cat. no.10342-053)

-dATP 10 mM (Invitrogen, cat. no. 10297-018)

- TA cloning kit pGEM-T Vector system I (Promega, cat. no. A3600)

- Bacteria: JM 109 (heat-shock, Promega cat. no. L2001) or electroMAX

DH10B-T1R (electroporation, Invitrogen, cat. no. 12033-015)

-Electroporation cuvette $2 \mathrm{~mm}$ (Eurogentec, cat. no. CE-0002 50)

- IPTG (Invitrogen, cat. no. 15529-019)

-X-Gal (Q biogen, cat. no., 4063-102)

- N,N-dimethylformamide (Merck, cat. no. 1.03034.1000)

- Trypcase Soja Agar plates (BioMérieux, cat. no. 43019)

- Trypto-Casein-Soy (TCS) broth (Bio-Rad, cat. no. 53454)

- Ampicillin (Roche, cat. no. 835 242)

- $\mathrm{HCl}, 5 \mathrm{M}$ (Merck, cat. no.1.09911.0001)

-T7 PROM primer: 5'-TAATACGACTCACTATAGGG-3' EQUIPMENT

-Ultrasound sonicator (Vibra Cell 75041, Bioblock) and ultrahigh-intensity

$3 \mathrm{~mm}$ tapered microtip

- Sequencher software program (Gene Codes Corporation)

- Electroporation device (Gene Pulser II, Bio-Rad)

REAGENT SETUP

IPTG $20 \mathrm{mg} \mathrm{ml}^{-1}$ stock solution Dissolve $200 \mathrm{mg}$ powder in $10 \mathrm{ml}$ distilled water. Filter on $0.2 \mu \mathrm{m}$ filters, aliquot and store at $-20{ }^{\circ} \mathrm{C}$.
$\mathrm{X}$-Gal $40 \mathrm{mg} \mathrm{ml}^{-1}$ stock solution Dissolve $1 \mathrm{~g}$ powder (i.e., the content of one flask) in $25 \mathrm{ml} \mathrm{N}, \mathrm{N}$-dimethylformamide. Aliquot and store at $-20^{\circ} \mathrm{C}$

! CAUTION N, N-dimethylformamide is toxic (see Material Safety Data Sheet at http://uk.chemdat.info/mda/uk). Handle the solution under a chemical fume hood, and do not use polystyrene tips or vials because they will be dissolved. Ampicillin $100 \mathbf{~ m g ~ m l}^{-1}$ stock solution Dissolve the powder in water, aliquot and store at $-20^{\circ} \mathrm{C}$.

Agar plate preparation The blue/white screening is used to select colonies that contain an insert. IPTG induces the $\beta$-galactosidase reporter gene (lacZ) that hydrolyzes the X-Gal substrate, resulting in a blue coloration. Insertional inactivation of the reporter gene allows recombinant clones to be directly identified by color screening, as those colonies remain white. For one plate, spread $40 \mu \mathrm{l}$ IPTG stock solution, $40 \mu \mathrm{l}$ X-Gal stock solution and $20 \mu \mathrm{l}$ ampicillin stock solution. Incubate upside down for $1 \mathrm{~h}$ at room temperature $\left(20-25^{\circ} \mathrm{C}\right)$ before use to allow the reagents to diffuse into the agar prior to bacterial spreading. $\triangle$ CRITICAL Prepare the plates at least $1 \mathrm{~h}$ before spreading the bacteria. Alternatively, they can be prepared a few days before, stored at $4{ }^{\circ} \mathrm{C}$ and kept at room temperature $\left(20-25{ }^{\circ} \mathrm{C}\right) 1 \mathrm{~h}$ before use.

HCl, $0.1 \mathrm{M}$ Dilute $5 \mathrm{M} \mathrm{HCl} 1 / 50$ in distilled water. ! CAUTION $5 \mathrm{M} \mathrm{HCl}$ is an irritant (see Material Safety Data Sheet at http://uk.chemdat.info/mda/uk). Experimental design for PCR amplification PCR or RT-PCR can be performed using either specific or degenerate primers. Amplified DNA should be checked by gel electrophoresis before starting the LoPPS procedure. It is not necessary to purify the DNA unless nonspecific amplicons $>400 \mathrm{bp}$ are observed. In the latter case, the target product should be gel purified prior to LoPPS. EQUIPMENT SETUP

Sonicator Place the $3 \mathrm{~mm}$ tapered microtip on the sonicator and set the amplitude control to $20 \%$.

Electroporation device Set the resistance to $200 \mathrm{ohms}$, voltage to 2,000 V and capacitance to $25 \mu \mathrm{F}$.

\section{PROCEDURE}

\section{Shearing of DNA by sonication $\bigcirc$ TIMING 5 min}

1) Transfer the DNA sample (from 0.2 to $20 \mu \mathrm{g}$ of PCR reaction) to a $1.5 \mathrm{ml}$ microfuge tube and make up to $250 \mu \mathrm{l}$ final volume with distilled water.

2) Place the $3 \mathrm{~mm}$ microtip of the sonicator in the sample.

$\triangle$ CRITICAL STEP Avoid contact between the microtip and the tube, as the tube could burst.

3| Perform three $5 \mathrm{~s}$ pulses, each separated by $5 \mathrm{~s}$.

! CAUTION Use ear protection against ultrasound.

$\triangle$ CRITICAL STEP The target size of sheared products is $\sim 700 \mathrm{bp}$. More pulses or longer pulses will produce shorter sheared fragments. The progress of shearing may be checked by agarose gel electrophoresis after Step 6 (concentration of DNA may be required for visualization): a smear centered around $700-1,000$ bp should be observed. Reassessment of shearing conditions may be required to process products significantly higher than $5 \mathrm{~kb}$.

4| Remove the tube and rinse the microtip with $0.1 \mathrm{M} \mathrm{HCl}$ followed by distilled water.

PAUSE POINT Sample can be stored at $4{ }^{\circ} \mathrm{C}$ up to 1 week.

\section{Column purification $\bigcirc$ TIMING 15 min}

5| Transfer $250 \mu \mathrm{l}$ sheared DNA onto the Nanosep 100K column.

$\triangle$ CRITICAL STEP If other columns are used, check by agarose gel electrophoresis that they efficiently remove fragments $<400 \mathrm{bp}$ (this is critical to ensure efficient ligation). 
6| Centrifuge at 3,000 r.p.m. to reach a volume of $\sim 15 \mu$ l, i.e., 5-15 min depending on the DNA concentration.

$\triangle$ CRITICAL STEP If the entire sample has gone through the membrane, recover the DNA by adding distilled water (15 $\mu$ ) onto the column and incubating at room temperature $\left(20-25^{\circ} \mathrm{C}\right)$ for $5 \mathrm{~min}$.

PAUSE POINT Sample can be stored at $4^{\circ} \mathrm{C}$ up to 1 week.

\section{DNA polishing with DNA Terminator End Repair Kit $\bigcirc$ TIMING 70 min}

7| Transfer the entire sample of purified sheared DNA from Step 6 into a $0.5 \mathrm{ml}$ microfuge tube.

8| Set up a $50 \mu$ l polishing reaction as described in the table below.

\begin{tabular}{lc}
\hline Stock component & Volume \\
\hline Purified sheared DNA & $15 \mu \mathrm{l}$ \\
$5 \times$ buffer (kit) & $10 \mu \mathrm{l}$ \\
Enzyme (kit) & $2 \mu \mathrm{l}$ \\
$\mathrm{H}_{2} 0$ up to $50 \mu \mathrm{l}$ & $23 \mu \mathrm{l}$ \\
\hline
\end{tabular}

9| Incubate at room temperature $\left(20-25^{\circ} \mathrm{C}\right)$ for $30 \mathrm{~min}$.

$\triangle$ CRITICAL STEP Incubation for longer than $30 \mathrm{~min}$ at room temperature may damage DNA.

10| Stop the reaction by heating the tube at $70{ }^{\circ} \mathrm{C}$ for $15 \mathrm{~min}$.

11 Add $200 \mu \mathrm{l}$ distilled water, and apply the mixture onto the Nanosep 100K column.

12| Column purify as described in Step 6.

- PAUSE POINT Sample can be stored at $4{ }^{\circ} \mathrm{C}$ up to 1 week.

Addition of $\mathbf{3}^{\prime}$ A-overhangs $\bigcirc$ TIMING $\mathbf{5 0}$ min

13| Transfer all of the purified sample from Step 12 to a $0.5 \mathrm{ml}$ microfuge tube.

14| Set up a $50 \mu \mathrm{l}$ reaction as detailed in the table below.

\begin{tabular}{lc}
\hline Stock component & Standard reaction \\
\hline Polished DNA & $15 \mu \mathrm{l}$ \\
$10 \times \mathrm{PCR}$ buffer & $5 \mu \mathrm{l}$ \\
$50 \mathrm{mM} \mathrm{MgCl}$ & $1.5 \mu \mathrm{l}$ \\
$10 \mathrm{mM} \mathrm{dATP}$ & $2 \mu \mathrm{l}$ \\
Taq DNA polymerase & $2 \mu \mathrm{l}(10 \mathrm{U})$ \\
$\mathrm{H}_{2} \mathrm{O}$ up to $50 \mu \mathrm{l}$ & $1.5 \mu \mathrm{l}$ \\
\hline
\end{tabular}

15| Incubate at $72{ }^{\circ} \mathrm{C}$ for $30 \mathrm{~min}$.

16 Make the volume up to $250 \mu \mathrm{l}$ with distilled water and purify on Nanosep 100K column as described in Step 6 .

PAUSE POINT Sample can be stored at $4{ }^{\circ} \mathrm{C}$ up to 1 week.

Ligation with pGEM-T Vector System I kit $\bigcirc$ TIMING 5 min handling, incubation overnight

17| Transfer $3 \mu \mathrm{l}$ DNA from Step 16 to a $0.5 \mathrm{ml}$ microfuge tube.

18| Set up a $10 \mu \mathrm{l}$ reaction as detailed in the table below. Include a positive control, as indicated.

\begin{tabular}{lcc}
\hline Stock component & Standard reaction & Positive control \\
\hline DNA from Step 16 & $3 \mu \mathrm{l}$ & - \\
Control insert DNA & - & $2 \mu \mathrm{l}$ \\
2× T4 DNA ligase buffer (kit) & $5 \mu \mathrm{l}$ & $5 \mu \mathrm{l}$ \\
PGEM-T vector (kit) & $1 \mu \mathrm{l}$ & $1 \mu \mathrm{l}$ \\
T4 DNA ligase (kit) & $1 \mu \mathrm{l}$ & $1 \mu \mathrm{l}$ \\
$\mathrm{H}_{2} \mathrm{O}$ & - & $1 \mu \mathrm{l}$ \\
\hline
\end{tabular}

19| Incubate overnight at $10^{\circ} \mathrm{C}$.

$\triangle$ CRITICAL STEP The manufacturer's manual states that incubation maybe performed for $1 \mathrm{~h}$ at room temperature. However, overnight incubation will produce the maximum number of transformants for fragments around $700 \mathrm{bp}$.

PAUSE POINT Sample can be stored at $4^{\circ} \mathrm{C}$ up to 1 week. 


\section{Transformation TIMING 120 min, incubation overnight}

20| This step can be performed either by heat-shock (A) or by electroporation (B). Include the positive control from Step 19.

$\triangle$ CRITICAL STEP Agar plates must be prepared 60 min before spreading bacterial suspension (see REAGENT SETUP section).

(A) Heat shock

(i) Thaw a $40 \mu$ l aliquot of JM109 bacteria on ice.

(ii) Add $2.5 \mu$ l ligated product, and mix gently by stirring with pipette tip.

(iii) Incubate on ice for $30 \mathrm{~min}$.

(iv) Heat shock for exactly $45 \mathrm{~s}$ in a $42{ }^{\circ} \mathrm{C}$ water bath.

(v) Place the tube on ice immediately and incubate for $2 \mathrm{~min}$.

(vi) Gently add $450 \mu \mathrm{l}$ warm TCS broth $\left(42{ }^{\circ} \mathrm{C}\right)$.

(vii) Shake the tube at 250 cycles per minute for $90 \mathrm{~min}$ at $37^{\circ} \mathrm{C}$.

(viii) Spread 80 and $160 \mu \mathrm{l}$ of bacterial suspension onto agar plates containing ampicillin, X-gal and IPTG.

(ix) Incubate the plates overnight at $37^{\circ} \mathrm{C}$.

\section{(B) Electroporation}

(i) Place the electroporation cuvette on ice for $5 \mathrm{~min}$.

(ii) Transfer $20 \mu \mathrm{L}$ DH10B-T1R bacteria to each cuvette.

(iii) Add $2.5 \mu$ ligation mixture, and mix gently with the pipette tip.

(iv) Dry the bottom of the tank before electroporation.

(v) Perform the electric shock (see EQUIPMENT SETUP).

(vi) Immediately place the cuvette on ice for $2 \mathrm{~min}$.

(vii) Add $450 \mu \mathrm{l}$ warm TCS broth $\left(42^{\circ} \mathrm{C}\right)$.

(viii) Transfer the bacteria to a $15 \mathrm{ml}$ tube.

(ix) Shake the tube at 250 cycles per minute for 90 min at $37^{\circ} \mathrm{C}$.

(x) Spread 80 and $160 \mu \mathrm{l}$ of bacterial suspension onto agar plates containing ampicillin, X-gal and IPTG.

(xi) Incubate the plates overnight at $37^{\circ} \mathrm{C}$.

\section{? TROUBLESHOOTING}

\section{Clone selection}

21 Determine the number of clones to be processed $(N)$ according to the length of the PCR product using one of the formulae presented in Table 1. This number takes into account the setback percentage resulting from: (i) false-positive colonies, (ii) clones with shorter inserts than expected and (iii) failure of the sequencing reaction. It is not necessary to overestimate $N$ for a target up to $5 \mathrm{~kb}$. Processing larger products may require reassessment of $N$.

22| Select white colonies and process them for sequencing with T7 PROM primer according to the high-throughput platform recommendations or a standard laboratory procedure. Colonies may be (i) grown in standard media containing ampicillin before plasmid extraction; (ii) selected and transferred to another agar plate; or (iii) inserts may be amplified with M13 primers to sequence PCR products.

$\triangle$ CRITICAL STEP Do not prime the sequencing reaction with M13 primers, as they are more distant from the insert than T7 PROM primer and would reduce the length of the informative sequence read.

\section{Analysis of sequence data}

23| Import the chromatograms into the Sequencher software program.

$\triangle$ CRITICAL STEP Any software that enables sequence assembly may be used.

24| Use the 'trim vector' and 'trim ends' functions with default parameters to remove plasmid sequences and ambiguous termini (bases are trimmed until the first $25 \mathrm{nt}$ contain less than three ambiguities).

25 Assemble the contig automatically by using the 'dirty data' algorithm and starting with a minimum match percentage of $90 \%$ and a minimum overlap of 20 bases. These values may be lowered to add the remaining sequences whose chromatograms may display more ambiguities.

\section{? TROUBLESHOOTING}

26| Correct the resulting contig manually for ambiguous bases and overlapping regions. The time required to construct the final sequence depends on its size and on the quality of chromatograms (in our experience, it takes about $1 \mathrm{~h}$ to construct and correct a 4,000 bp contig).

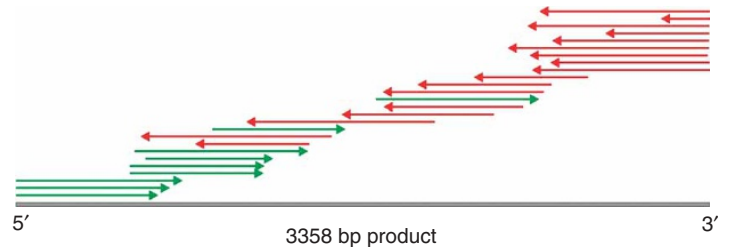

Figure 2 | Screenshot of a typical contig assembly for a 3375 bp PCR product. Red arrows are forward sequences and green arrows are reverse sequences. 


\section{TIMING}

Steps 1-4, sonication: 5 min

Steps 5 and 6 , column purification: $15 \mathrm{~min}$

Steps 7-12, DNA polishing: $70 \mathrm{~min}$

Steps 13-16, addition of A-overhangs: 50 min

Steps 17-19, ligation: 5 min and overnight step

Step 20, transformation: 120 min and overnight step

\section{? TROUBLESHOOTING}

Troubleshooting advice can be found in Table 2 .

TABLE 2 | Troubleshooting table.

\begin{tabular}{ll}
\hline Problem & Possible reason \\
\hline Step 20: Few colonies on agar plates & Inefficient ligation or transformation
\end{tabular}

\section{Solution}

\section{Repeat the reaction from Step 18}

Include positive controls to monitor ligation and transformation

Avoid multiple freeze-thawing of the plasmid (loss of $5^{\prime}$ T-overhang)

Step 20: Few white colonies but many blue colonies

Step 25: Over-representation of extremities in the contig

Step 25: Incomplete sequence

Number of clones sequenced too low

Steps 25 or 26: Sequencing reveals cloning of concatenated fragments
Insert size too small

Damage of DNA due to long UV exposure during gel-purification

Inappropriate $\mathrm{PCR}$ product quantities

Damage of DNA due to incubation longer than 30 min during polishing step

Polishing of fragments not properly achieved

3' A-overhangs not properly added

3'A-overhangs not properly added

Fragments $<300 \mathrm{bp}$ not properly removed
Limit UV exposure by purifying only one target product at a time

Use 0.2-20 $\mu \mathrm{g}$ DNA

Ensure that Steps 9 and 10 are carried out correctly

Ensure that Steps 7-16 are carried out correctly

Check the capability of the polymerase to add 3' A-overhangs

Use Table 1 to determine the number of clones to sequence. For products larger than $5 \mathrm{kbp}$, determine experimentally which values may be used in the equation provided

Check the size of sheared products by gel electrophoresis Use the Nanosep 100K columns and do not spin at $>3,000$ r.p.m. Visualize the results by gel electrophoresis before and after purification

Ensure a ligation at low temperature for several hours

Use only the TA cloning strategy, which substantially lowers the probability of concatenation

Use purification columns that efficiently remove the shortest fragments

\section{ANTICIPATED RESULTS}

We have used the LoPPS procedure to characterize 24 different PCR products whose size ranged from 2,579 to 4,766 nt ${ }^{35}$. All products were fully sequenced, and each nucleotide was read 4.4 times by mean. For example, we sequenced a 3,358 bp PCR product by processing 30 clones. The final contig was obtained from 26 sequences ranging from 233 to 984 nt long with an average on 732 nt. All positions were read two to nine times, and inserts were homogeneously distributed along the products as shown in Figure 2.

ACKNOWLEDGMENTS S. Emonet's salary was supported by the Délégation Générale pour l'Armement. This work was partly funded by the European Commission through the VIZIER Integrated Project (LSHG-CT-2004-511966) in the sixth Framework Programme for Research and Technological Development.

AUTHOR CONTRIBUTIONS Drs. Emonet and Grard contributed equally to this work.

COMPETING INTERESTS STATEMENT The authors declare that they have no competing financial interests.
Published online at http://www.natureprotocols.com

Reprints and permissions information is available online at http://npg.nature.com/ reprintsandpermissions

1. Fleischmann, R.D. et al. Whole-genome random sequencing and assembly of Haemophilus influenzae Rd. Science 269, 496-512 (1995).

2. Venter, J.C. et al. The sequence of the human genome. Science 291, 1304-1351 (2001).

3. Venter, J.C. et al. Environmental genome shotgun sequencing of the Sargasso Sea. Science 304, 66-74 (2004). 
4. Goff, S.A. et al. A draft sequence of the rice genome (Oryza sativa L. ssp. japonica). Science 296, 92-100 (2002).

5. Adams, M.D. et al. The genome sequence of Drosophila melanogaster. Science $\mathbf{2 8 7}$ 2185-2195 (2000)

6. Jones, T. et al. The diploid genome sequence of Candida albicans. Proc. Natl. Acad. Sci. USA 101, 7329-7334 (2004).

7. Weber, J.L. \& Myers, E.W. Human whole-genome shotgun sequencing. Genome Res. 7, 401-409 (1997).

8. Sanger, F., Nicklen, S. \& Coulson, A.R. DNA sequencing with chain-terminating inhibitors. Proc. Natl. Acad. Sci. USA 74, 5463-5467 (1977).

9. Margulies, M. et al. Genome sequencing in microfabricated high-density picolitre reactors. Nature 437, 376-380 (2005).

10. Shendure, J. et al. Accurate multiplex polony sequencing of an evolved bacterial genome. Science 309, 1728-1732 (2005).

11. Dressman, D., Yan, H., Traverso, G., Kinzler, K.W. \& Vogelstein, B. Transforming single DNA molecules into fluorescent magnetic particles for detection and enumeration of genetic variations. Proc. Natl. Acad. Sci. USA 100, 8817-8822 (2003).

12. Ronaghi, M. Pyrosequencing sheds light on DNA sequencing. Genome Res. 11, 3-11 (2001).

13. Reed, S.E., Tsai, C.W., Willie, K.J., Redinbaugh, M.G. \& Hogenhout, S.A. Shotgun sequencing of the negative-sense RNA genome of the rhabdovirus Maize mosaic virus. J. Virol. Methods 129, 91-96 (2005).

14. Hardin, S.H., Jones, L.B., Homayouni, R. \& McCollum, J.C. Octamer-primed cycle sequencing: design of an optimized primer library. Genome Res. 6, 545-550 (1996).

15. Siemieniak, D.R. \& Slightom, J.L. A library of 3342 useful nonamer primers for genome sequencing. Gene 96, 121-124 (1990).

16. Studier, F.W. A strategy for high-volume sequencing of cosmid DNAs: random and directed priming with a library of oligonucleotides. Proc. Natl. Acad. Sci. USA $\mathbf{8 6}$ 6917-6921 (1989).

17. Szybalski, W. Proposal for sequencing DNA using ligation of hexamers to generate sequential elongation primers (SPEL-6). Gene 90, 177-178 (1990).

18. Kieleczawa, J., Dunn, J.J. \& Studier, F.W. DNA sequencing by primer walking with strings of contiguous hexamers. Science 258, 1787-1791 (1992).

19. Azhikina, T. et al. Strings of contiguous modified pentanucleotides with increased DNA-binding affinity can be used for DNA sequencing by primer walking. Proc. Natl. Acad. Sci. USA 90, 11460-11462 (1993).

20. Kotler, L.E., Zevin-Sonkin, D., Sobolev, I.A., Beskin, A.D. \& Ulanovsky, L.E. DNA sequencing: modular primers assembled from a library of hexamers or pentamers. Proc. Natl. Acad. Sci. USA 90, 4241-4245 (1993).

21. Kaczorowski, T. \& Szybalski, W. Assembly of 18-nucleotide primers by ligation of three hexamers: sequencing of large genomes by primer walking. Anal. Biochem. 221, 127-135 (1994).
22. Kaczorowski, T. \& Szybalski, W. Genomic DNA sequencing by SPEL-6 primer walking using hexamer ligation. Gene 223, 83-91 (1998).

23. Lashkari, D.A., Hunicke-Smith, S.P., Norgren, R.M., Davis, R.W. \& Brennan, T. An automated multiplex oligonucleotide synthesizer: development of high-throughput, low-cost DNA synthesis. Proc. Natl. Acad. Sci. USA 92, 7912-7915 (1995)

24. Rayner, S. et al. MerMade: an oligodeoxyribonucleotide synthesizer for high throughput oligonucleotide production in dual 96-well plates. Genome Res. 8 741-747 (1998).

25. Gromek, K. \& Kaczorowski, T. DNA sequencing by indexer walking. Clin. Chem. $\mathbf{5 1}$ 1612-1618 (2005).

26. Barnes, W.M. PCR amplification of up to 35-kb DNA with high fidelity and high yield from lambda bacteriophage templates. Proc. Natl. Acad. Sci. USA 91, 2216-2220 (1994).

27. Cheng, S., Fockler, C., Barnes, W.M. \& Higuchi, R. Effective amplification of long targets from cloned inserts and human genomic DNA. Proc. Natl. Acad. Sci. USA 91, 5695-5699 (1994).

28. Gritsun, T.S. \& Gould, E.A. Development and analysis of a tick-borne encephalitis virus infectious clone using a novel and rapid strategy. J. Virol. Methods $\mathbf{7 6}$, 109-120 (1998).

29. Lindberg, A.M., Polacek, C. \& Johansson, S. Amplification and cloning of complete enterovirus genomes by long distance PCR. J. Virol. Methods. 65, 191-199 (1997).

30. Zhang, F. et al. Amplification and cloning of the full-length genome of Japanese encephalitis virus by a novel long RT-PCR protocol in a cosmid vector. J. Virol. Methods 96, 171-182 (2001).

31. Selisko, B. et al. Comparative mechanistic studies of de novo RNA synthesis by flavivirus RNA-dependent RNA polymerases. Virology 351, 145-158 (2006).

32. Takita, Y., Takahara, M., Nogami, S., Anraku, Y. \& Ohya, Y. Applications of the long and accurate polymerase chain reaction method in yeast molecular biology: direct sequencing of the amplified DNA and its introduction into yeast. Yeast $\mathbf{1 3}$ 763-768 (1997).

33. Ponce, M.R. \& Micol, J.L. PCR amplification of long DNA fragments. Nucleic Acids Res. 20, 623 (1992).

34. Chouljenko, V., Jayachandra, S., Rybachuk, G. \& Kousoulas, K.G. Efficient long-PCR site-specific mutagenesis of a high GC template. Biotechniques 21, 472-474-476-478 480 (1996).

35. Emonet, S. et al. LoPPS: a long PCR product sequencing method for rapid characterisation of long amplicons. Biochem. Biophys. Res. Commun. 344, 1080-1085 (2006).

36. Clarke, L. \& Carbon, J. A colony bank containing synthetic Col El hybrid plasmids representative of the entire $E$. coli genome. Cell 9, 91-99 (1976). 